\title{
THE IMPACT OF GEOMORPHOLOGICAL FACTORS ON THE DISTRIBUTION OF TYPICAL DWELLINGS IN NORTHERN CHINA
}

\author{
Qibo $\mathrm{LIU}^{1 *}$ and Bei SHANG ${ }^{2}$
}

${ }^{1}$ Department of Architecture, Chang'an University, Xi'an 710061, China

${ }^{2}$ Design Department, Yinchuan Planning and Architecture Design Institute, Yinchuan 750001, China

*Corresponding author: linka_0@163.com

(Received May 2018; accepted July 2018)

Key words: traditional northern dwelling, type traits, geomorphological region, local characteristics, natural environment

\begin{abstract}
Traditional settlements and dwellings, as an important part of the Chinese architecture culture, not only embody the ecological philosophy of the harmonious coexistence of the architecture and nature, but also reflect the technical wisdom and experience of traditional craftsmen. They prove a treasure for studying the native green thoughts and architectural technologies. Studying traditional settlements based on natural environmental factors such as the climate, landform, etc. is a process that explores the essential elements of the regional characters and reveals the genuine local connotation. By probing into the relations between the types of typical dwellings in northern China and natural factors such as the landform and climate, this study attempts to unveil the essential connotation of regional characters, pave the way for studies on the green technical elements of traditional dwellings, provide theoretical and practical support for the ever-advancing protection and development of traditional settlements, and offer some insights into developing regional architecture today. Focused on the architecture in northern China, this study compared and analysed the types and distribution pattern of dwellings in different climatic regions, architectural thermal zones, and geomorphological regions, and made a more detailed classification of the architectural types of courtyard houses based on previous studies on typical dwellings in northern China. Specifically, quadrangle courtyards were further classified into the Beijing-Hebei type, the Shanxi-Shaanxi type, and the Manchu type. Moreover, a distribution mapping of typical dwellings in northern China was drawn based on geomorphological regions. Building on this, a comprehensive case study was carried out and a distribution mapping of typical northern dwellings was drawn, paving the way for studies on the green technical elements of traditional dwellings, further revealing the close relationship between the local characteristics of dwellings and those of the natural environment, and presenting the typical value and local characteristic connotation of dwellings in different regions based on natural division.
\end{abstract}

Palabras clave: asentamientos tradicionales del norte, características tipo, región geomorfológica, características locales, ambiente natural

\section{RESUMEN}

Las viviendas y asentamientos tradicionales, como parte importante de la cultura arquitectónica de China, no sólo comprenden la filosofía ecológica de la coexistencia armoniosa entre arquitectura y naturaleza, sino que también reflejan la sabiduría técnica y la experiencia 
de los artesanos tradicionales. Ellos son un tesoro para el estudio del pensamiento verde y las tecnologías arquitectónicas. El estudio de los asentamientos tradicionales con base en factores ambientales como los accidentes geográficos, el clima, etc., es un proceso que explora los elementos esenciales de los caracteres regionales y revela las connotaciones locales genuinas. Al explorar las relaciones entre las clases de asentamientos tradicionales típicos en el norte de China y los factores naturales como los accidentes geográficos y el clima, este estudio intenta develar la connotación esencial de los caracteres regionales, abrir el camino para investigaciones sobre los elementos técnicos verdes de los asentamientos tradicionales, proporcionar apoyo teórico y práctico para la siempre creciente protección y desarrollo de los asentamientos tradicionales y, ofrecer algunas percepciones sobre el desarrollo regional de la arquitectura en la actualidad. Concentrándose en la arquitectura del norte de China, este estudio compara y analiza los tipos de patrones de distribución de los asentamientos en diferentes regiones climáticas, zonas térmicas arquitectónicas y regiones geomorfológicas y hace una clasificación más detallada de los tipos de casas con patios con base en estudios previos sobre asentamientos tradicionales en el norte de China. Específicamente, los patios cuadrangulares fueron clasificados como tipos BeijingHebei, Shanxi-Shaanxi y Manchú. Adicionalmente, se dibujó un mapa de asentamientos tradicionales en el norte de China con base en regiones geomorfológicas. Con base en esto, se llevó a cabo un estudio de caso comprehensivo y se dibujó un mapa de asentamientos típicos del norte, allanando el camino para los estudios sobre elementos técnicos verdes en asentamientos tradicionales, revelando la cercana relación entre las características locales de los asentamientos y aquellas del ambiente natural y presentando el valor típico y las connotaciones locales características de los asentamientos en diferentes regiones con base en una división natural.

\section{INTRODUCTION}

Traditional settlements and dwellings, as an important part of the Chinese architecture culture, not only embody the ecological philosophy of the harmonious coexistence of the architecture and nature, but also reflect the technical wisdom and experience of traditional craftsmen. They prove a treasure for studying the native green thoughts and architectural technologies. Studying traditional settlements based on natural environmental factors such as the climate, landform, etc. is a process that explores the essential elements of the regional characters and reveals the genuine local connotation. (Chen 2009, CAS 1985, Li et al. 2018, Basheer et al. 2017).

However, as the urbanization and the urban-rural integration advance, a great number of traditional settlements have been demolished or transformed, and some valuable traditional settlements are not preserved in time, resulting in the extinction of many traditional architectural technologies and giving rise to the convergence of many architecture cultures and the loss of regional characters (Shen et al. 2017, Basak and Gajbhiye 2018, Neves et al. 2018, Yang 2014, Ismail and Hanafiah 2017). As an important type of traditional architecture, settlements are the places for living, rest, various social activities, and production (Yasin et al. 2017, Tariq et al. 2017). How to inherit and learn from the cultural and technical essences of traditional settlements and promote green architecture with Chinese cultural characteristics remains an urgent task.

By probing into the relations between the types of typical dwellings in northern China and natural factors such as the landform and climate, this study attempts to unveil the essential connotation of regional characters, pave the way for studies on the green technical elements of traditional dwellings, provide theoretical and practical support for the everadvancing protection and development of traditional settlements, and offer some insights into developing regional architecture today (Daya and Pant 2017).

\section{METHOD}

\section{Demarcation between the southern and northern China based on objects of study}

Physical geographical regionalization is a method for studying the regional distribution pattern of geographical phenomena and characteristics. (As a study method, regionalization observes and studies regional complexes from a regional perspective and discusses the differences and connections of objects of study 
within a regional unit. There are many proposals for physical geographical regionalization.) For example, the scheme for physical geographical regionalization of China published by Ren Mei'e and Yang Renzhang in 1961 divided China into eight natural regions based on the natural differences and different orientations of the utilization and transformation of nature, namely, Northeast China, North China, Central China, South China, Southwest China, Inner Mongolia, Northwest China, and Tibet (Fig.1) (Ren and Yang 1961, Sharma and Yadav 2017).

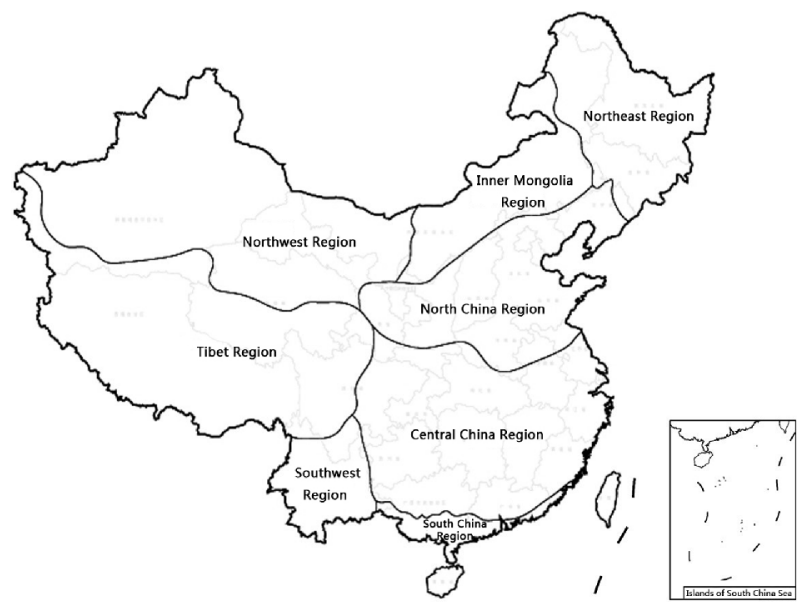

Fig. 1. The proposal for physical geographical regionalization of China by Ren Mei'e and Yang Renzhang in 1961 (Source: Modified and drawn by the author)

In Physical Geography in China: Overview compiled by the Editorial Board of Physical Geography in China under the Chinese Academy of Sciences in 1985, China was divided into three major natural regions, i.e., the Eastern Monsoon Region, the Northwestern Arid Region, and the Qinghai-Tibet Plateau Region (Hou and Wang 1999, Wang and Li 2017, Albrecht and Shaffer 2016, Franco et al. 2017). Each major natural region was then further divided into 7 natural regions and 33 natural sub-regions (Fig. 2) according to the combinations of temperature and water conditions and those combinations' reflections in soil, vegetation, etc. (Amin et al. 2018). Such a division in essence embodied the sign effect of waterheat combination on regionalization.

In a high school geography textbook with the same level of authority and popularity, China is divided into four geographical regions: the Northwest Region, the North Region, the Qinghai-Tibet Region, and the South Region. It synthesizes, generalizes, and

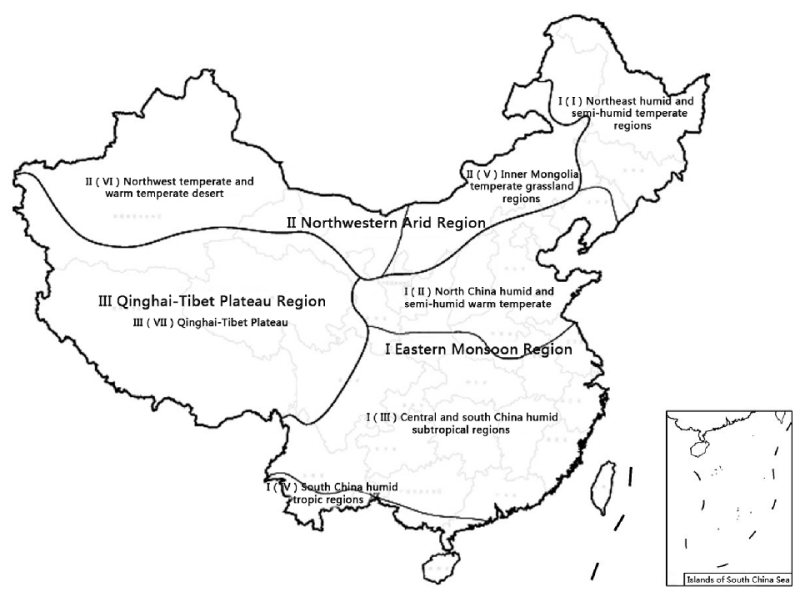

Fig. 2. Physical geographical regionalization of Physical Geography in China: Overview in 1983 (Source: Modified and drawn by the author)

simplifies the multiple regionalization proposals, thus becoming broadly popular (PEP, 2013, Shamsudin et al. 2017, Ghafar et al. 2017). Building on this, this study divides China into the southern region and the northern region (Fig. 3).

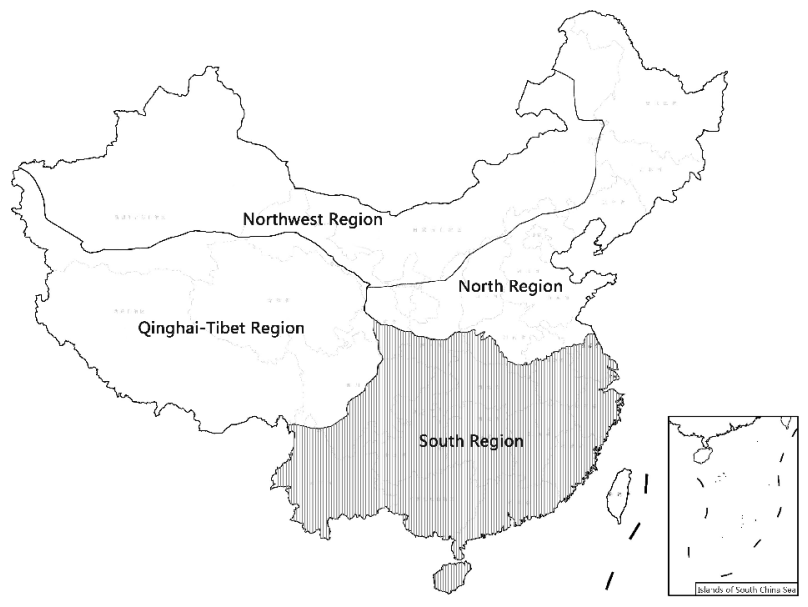

Fig. 3. Physical geographical regionalization in a high school geography textbook in China (Source: Modified and drawn by the author)

Regionalization, as a study method, is widely applied in various fields. The results of regionalization are different from the perspectives of other disciplines, but they somewhat overlap. The study of traditional Chinese dwellings, guided by the design philosophy of green architecture, focuses more on the adaptability of traditional dwellings to landforms and climates, because such adaptability originates from 
the ecological and natural characters of traditional dwellings and reflects their core value. Therefore, the study overlaps the physical geographical regionalization with the geomorphological regionalization map and the architecture climate zoning, respectively (Fig. 4, 5). It can be seen that in the geographical regionalization and geomorphological regionalization of the northern region, the Eastern Low Mountain and Plain Region I, the Northern Middle and High Mountains, Plain and Basin Region III, and the Qinghai-Tibet Plateau Region V highly coincide with zone I of severe cold region, zone II of cold region, zone VI of severe cold (cold) region, and zone VII of severe cold (cold) region in the architecture climate



Fig. 4. Overlap Map of Physical geographical regionalization and geomorphological regionalization (Source: Drawn by the author)

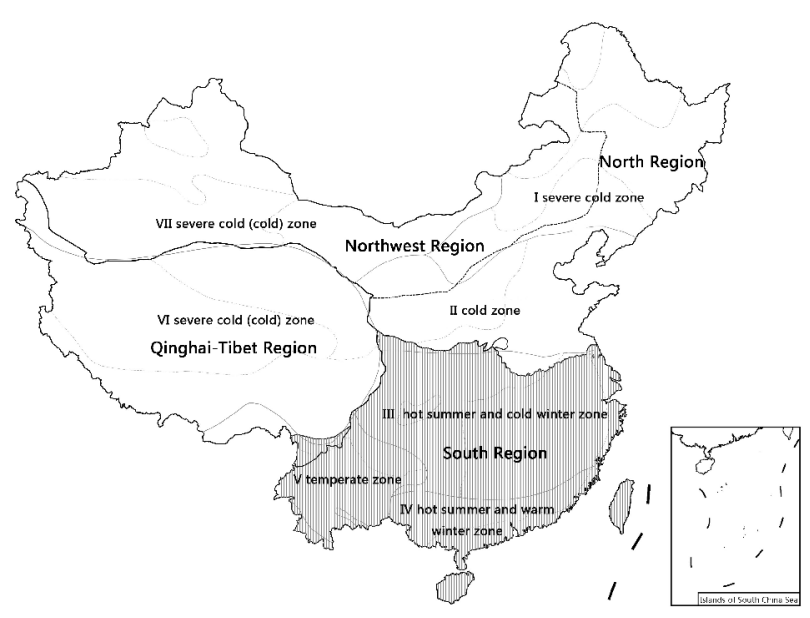

Fig. 5. Overlap Map of Physical geographical regionalization and architecture climate zone (Source: Drawn by the author) zoning. Therefore, considering them as an independent geomorphological unit in this study will help outline the green attributes of traditional dwellings from the two aspects of the landform and the climate.

\section{Types of typical dwellings in northern China}

In recent years, many standards and methods for classifying traditional dwellings have been developed as studies in this regard are deepened, e.g., by plane form, external appearance, building material, structural method, geography and climate, landform, living style, ethnic group and religion, culture, language, and natural conditions, etc., considering that the development of dwellings is related to social, cultural, and customs factors and is also influenced by natural conditions such as the climate and geography. Dwellings are designed and built by craftsmen using local materials and their own skills and experience. These factors all exert profound influence on the design and development of dwellings, so the features and classification of dwellings are presented in a comprehensive way.

This study outlines typical dwellings in northern China, building on previous studies, and conducts discussion mainly based on Liu Zhiping's A Brief History of Chinese Residential Architecture (Liu 2000). Since the architectural forms of small dwellings, such as the straight-line form, the regular square form, and the concave shape, are widely used in the northern region, simple in structure and not distinctly different from each other, they are excluded from the object of this study and the discussions of dwelling types and distribution.

Besides, some unique types of dwellings that are only distributed in a small number of regions, such as seaweed houses in Shangdong Province, are not included in the discussions, either.

After repeated comparisons, several broadly representative types of dwellings of multiple ethnic groups in various regions are selected as the main dwelling types in the northern region: the threesection courtyard, the quadrangle courtyard, the cave dwelling, the mongolian yurt, the Ayiwang, the blockhouse, and the ondol house of the Korean nationality. Among them, the quadrangle courtyard is subdivided into the Beijing-Hebei type, the ShanxiShaanxi type, and the Manchu type (Wang et al. 2009, Wang et al. 2009, Ye 2009, Zhou and Chen 2009, Zuo and Bai 2012).

\section{The three-section courtyards}

A three-section courtyard is a courtyard dwelling consisting of a principal room and the left and right 
wing-rooms. This type of dwellings is common in North China and is occasionally seen in Xinjiang Uygur Autonomous region and northern Jiangsu Province (Fig. 6).

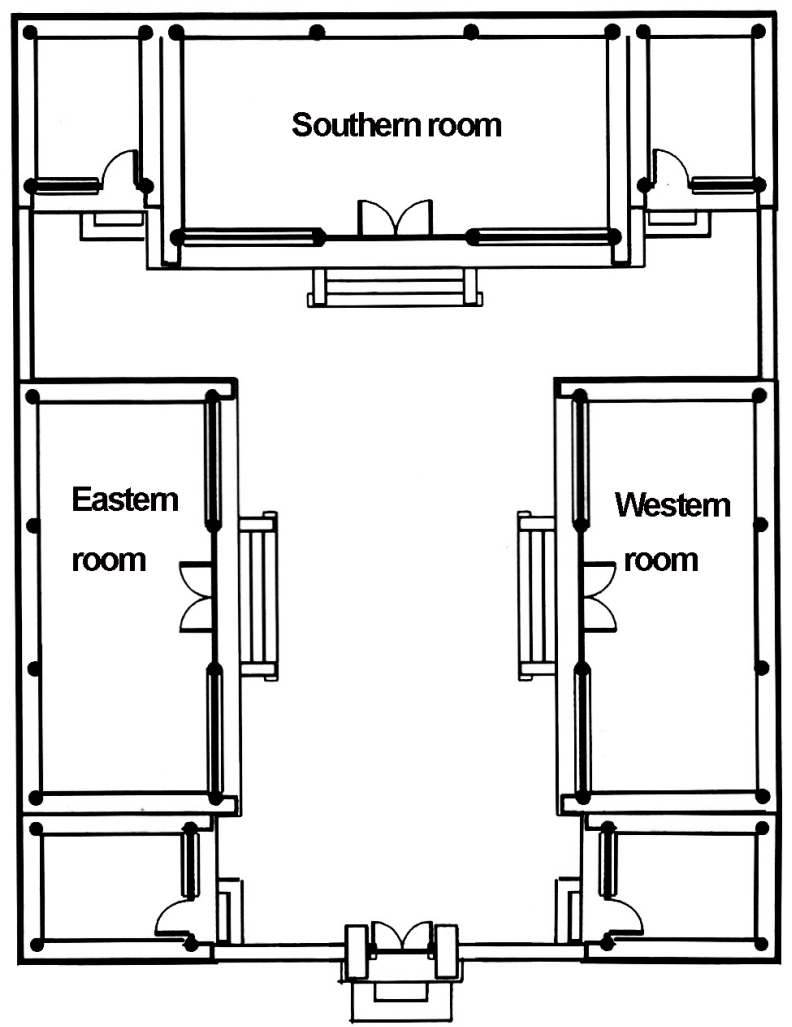

Fig. 6. The diagram of the three-section courtyard (Source: Drawn by the author)

\section{Quadrangle courtyards}

Liu Zhiping described quadrangle courtyards precisely in the A Brief History of Chinese Residential Architecture: "a quadrangle courtyard (also known as a four-section courtyard) is composed of a principal room, the left and right wing-rooms, and the servant's room". After studying the shape and structural differences of quadrangle courtyard dwellings in different regions, we classified the quadrangle courtyard into the "Beijing-Hebei type", the "Shanxi-Shaanxi type", and the "Manchu type" based on the relationships between the principal room and the wing-rooms.

\section{Quadrangle courtyards of the Beijing-Hebei type}

The quadrangle courtyard of the Beijing-Hebei type is a typical courtyard dwelling in the northern region (Fig. 7), whose prototype in terms of the shape, structure and layout is the quadrangle courtyards in Beijing and North China. Liu Zhiping pointed out that "ordinary scholars and businessmen in North China, Beijing, and adjacent areas mostly live in quadrangle courtyards". There are side rooms on both sides of the principal room or open spaces between the gables on both sides of the principal room and the courtyard walls, a feature of its plane form. The plane layout of a quadrangle courtyard of the Beijing-Hebei type is very similar to that of the ancient dwellings in the nine-rectangle-grid form, which looks like the Chinese character “井” or the traditional Chinese character “亜”, which is why Liu Zhiping named such dwellings as “亜”-shaped quadrangle courtyards.

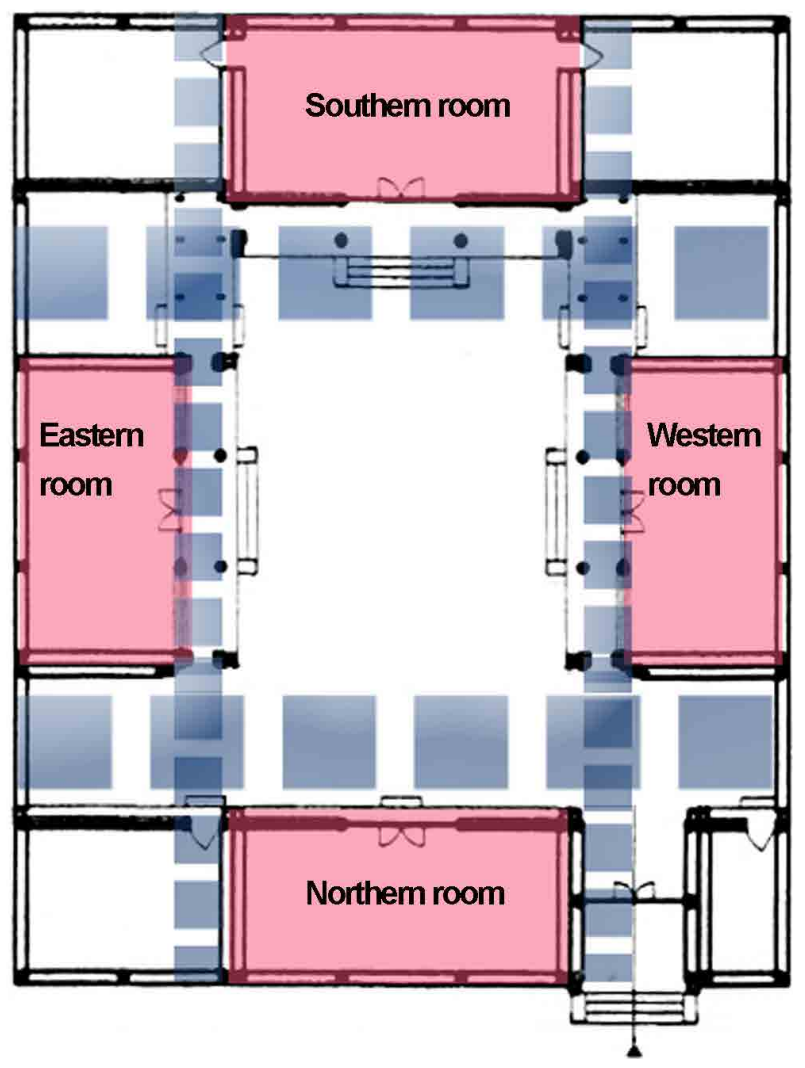

Fig. 7. A quadrangle courtyard of the Beijing-Hebei type (Source: Drawn by the author)

Some quadrangle courtyards in Henan Province and Shanxi Province are similar in the shape and structure to those of the Beijing-Hebei type, but they have no side rooms, so they may be called quadrangle courtyards of the Beijing-Hebei type without side rooms.

Quadrangle courtyards of the Beijing-Hebei type are mainly found in Beijing and surrounding areas, 
such as Shanxi Province, Hebei Province, Henan Province, and Northeast China, and occasionally in other regions and provinces in the northern region.

\section{Quadrangle courtyards of the Shanxi-Shaanxi type}

The quadrangle courtyard of the Shanxi-Shaanxi type is a courtyard dwelling widely used in Shanxi Province and Shaanxi Province (Fig. 8). Its plane form is characterized by the fact that the width of the principal room is equal to that of the yard and that the left and right wing-rooms are arranged between the principal room and the gate house. As Liu Zhiping pointed out, courtyard dwellings in Shanxi Province and Shaanxi Province are usually quadrangle courtyards in which wing-rooms are sandwiched between the principal room and the gate house. The exterior

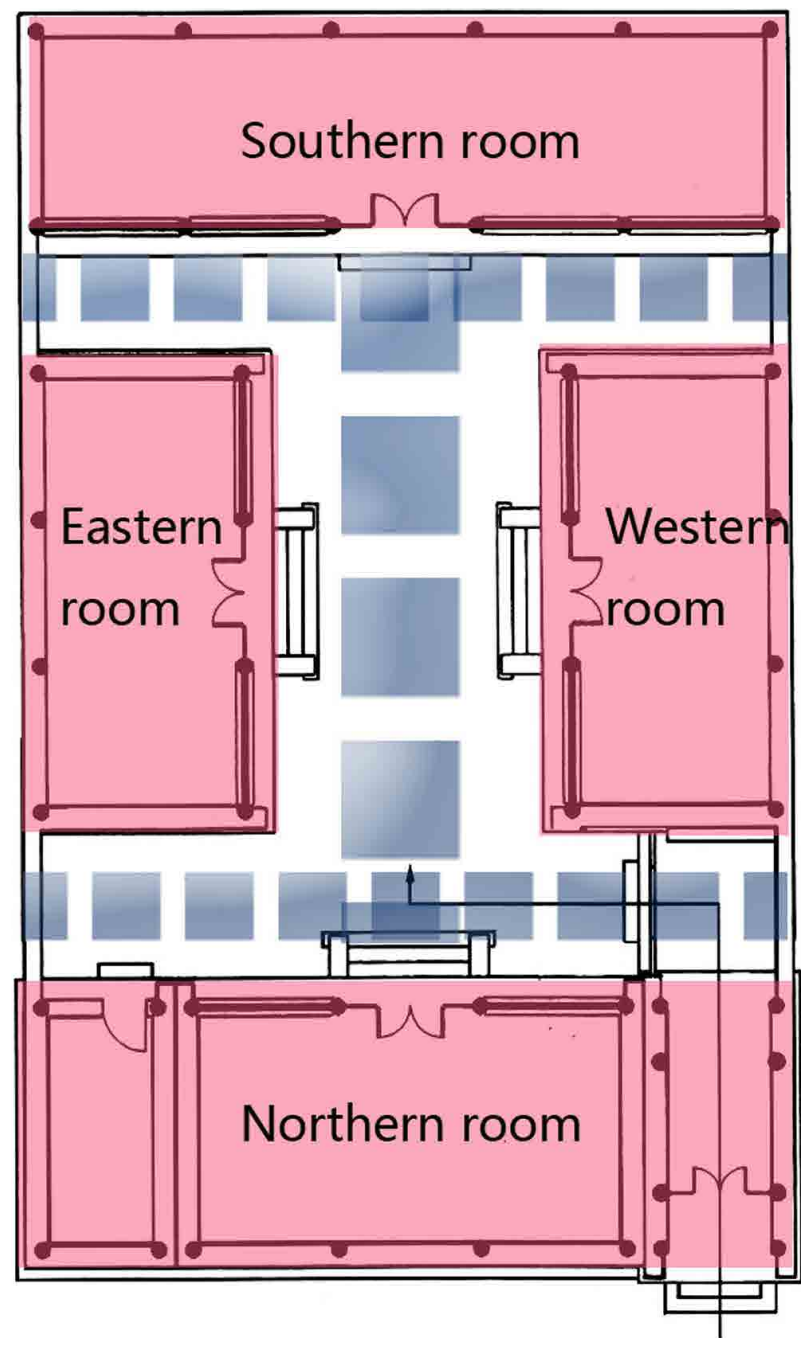

Fig. 8. A quadrangle courtyard of the Shanxi-Shaanxi type (Source: Drawn by the author) of a quadrangle courtyard of the Shanxi-Shaanxi type is similar to the Chinese character "工" in appearance, and this is why some scholars called it the "工"-shaped quadrangle courtyard.

Quadrangle courtyards of the Shanxi-Shaanxi type are further divided into the wide type and the narrow type. The narrow type usually has three principal rooms, one bright and two dark, while the wide type mostly has five principal rooms, three bright and two dark, with three wing-rooms, one on the left, one on the right, and one in the yard or front and back yards, respectively.

Quadrangle courtyards of the Beijing-Hebei type are mainly found in Shanxi Province and Northwest China, including Shaanxi Province and Gansu Province. They are also occasionally seen in Henan Province and Shandong Province.

\section{Quadrangle courtyards of the Manchu type}

Quadrangle courtyards of the north-eastern Manchu type have the same plane shape and structure with quadrangle courtyards of the Beijing-Hebei type, with some distinct Manchu characteristics. For example, compared with those of the Beijing-Hebei type, quadrangle courtyards of the Manchu type have a more spacious yard, which is shaped by the Manchu lifestyle as a nomadic people in the past and by the climatic conditions (Fig. 9). In addition, quadrangle courtyards of the Manchu type have a particular focus on high platforms. Therefore, we single them out as

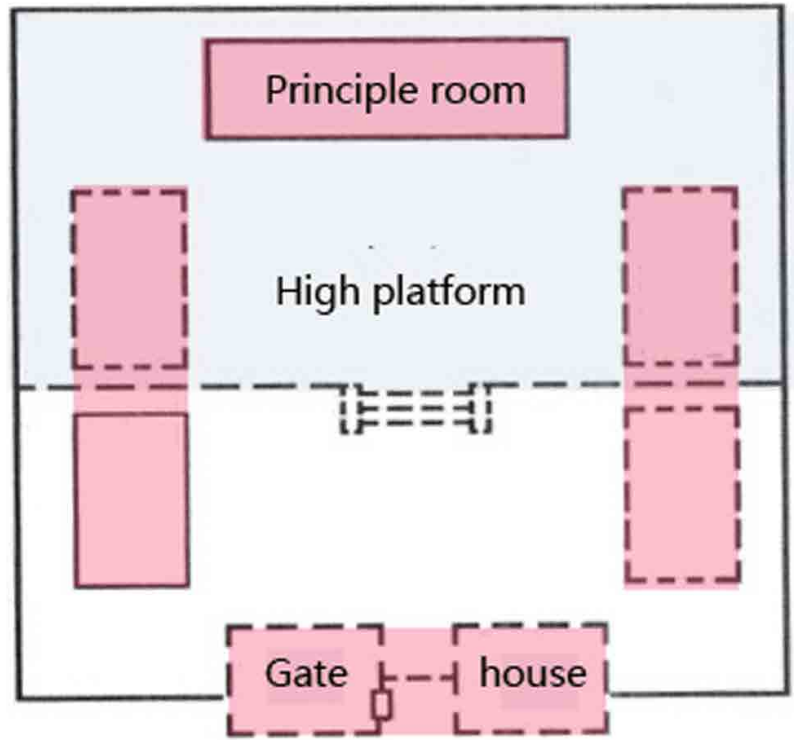

Fig. 9. A quadrangle courtyard of the Manchu type (Source: Drawn by the author) 
a separate type to demonstrate their differences from quadrangle courtyards of the Han nationality.

\section{The cave dwellings}

Liu Zhiping described cave dwellings in A Brief History of Chinese Residential Architecture as: "cave residences were all vertical at first, and later, horizontal cave residences were gradually used for living and vertical ones for storage". In the Qing Dynasty, in North China and the north-western loessial areas such as Henan, Shanxi, Shaanxi, and Gansu, cave residences were usually used for living, which are precedents for today's cave dwellings. Soil at these places is so solid and dry that it can be used to build a wall not liable to collapse; meanwhile, the climate in these regions is relatively dry, and the underground water level is very low, which are favourable conditions for cave digging. Cave dwellings are mostly distributed in the five provinces of Gansu, Shanxi, Shaanxi, Henan, and Ningxia, and a few can also be found in the midwest of Hebei Province and the middle of Inner Mongolia. Cave dwellings are mainly divided into the hillside type, the sunken type, and the independent type.

\section{The Mongolian yurts}

The Mongolian yurt is a unique dwelling of the Mongol nationality. It is considered by Liu Zhiping as the most successful work of non-settled architecture of nomads in Inner Mongolia, Xinjiang, etc. Such architecture had existed in the pre-Qin times and later was adopted by Chinese in the Han and Tang Dynasties because it is warm in winter. It was called the "dome" in the Han Dynasty and is also known as the yurt, the tent, and so on.

\section{The Ayiwang}

Ayiwang originally referred to the hall with a skylight of the Uyghur nationality in Xinjiang Uygur Autonomous region, and later became the synonym for the earth-wood dwellings with external corridors and flat roofs.

\section{The blockhouses}

The blockhouse is a common type of dwelling in the Qinghai-Tibet Plateau and some areas in Inner Mongolia. The blockhouse is built with stones or earth.

\section{The ondol houses of the Korean nationality}

"Ondol" is a characteristic space of the Korean nationality's dwellings -- a brick bed with underfloor heating. The dwellings of the Korean nationality come usually in straight-line forms or regular square forms, consisting mainly of a bedroom, a kitchen, and a storeroom. The main entrance is usually set in the direction of the kitchen and the bedroom is fully furnished with underfloor heating with a coiled flue, which allows the smoke from the kitchen to flow through the flue to the vent, reusing the waste heat from the kitchen. In this study, residences in straight-line forms and regular square forms are excluded due to their abundance and wide distribution. The brick bed with underfloor heating is one major feature of the Korean nationality's dwellings, so such architecture is called the "ondol house" of the Korean nationality. (The term "ondol" was derived from Japanese, and it's also an ancient Chinese term that is still used in North Korea and South Korea.)

\section{RESULTS}

\section{Geomorphological features of the distribution of typical dwellings in northern China}

Landform is a basic factor in the residential architectural composition, and it is often taken full advantage of and plays a supporting role in the composition and form of dwellings. The architectural form largely depends on the landform. Based on the definition of the northern region and the classification of dwellings in this study, we draw a distribution map of typical dwellings in different geomorphological regions in northern China (Fig. 10).

The distribution of major types of dwellings in different geomorphological regions can be observed from the map, as shown in Table I.

The only special landform in the table is Subregion IIB -- Huaiyang Low Mountains, which belongs to South-eastern Low and Middle Mountainous Region II. . Situated around the boundary between the south and the north, the majority of it is in the southern region.

The relationship between the distribution of typical dwellings and geomorphological features

Eastern Low Mountain and Plain Region I is located in the northern part of the third topography ladder (on the north of Dabie Mountain) in eastern China, with the Heilongjiang River on the north, the estuary of the Qiantang River on the south, the Yellow Sea, the Bohai Sea, and the East China Sea on the east, and the Greater Khingan Range on the west -- eastern foot of Taihang Mountains. Covering the Northeast Plain, it is China's largest plain area. Courtyard houses are mainly distributed in this region, such 


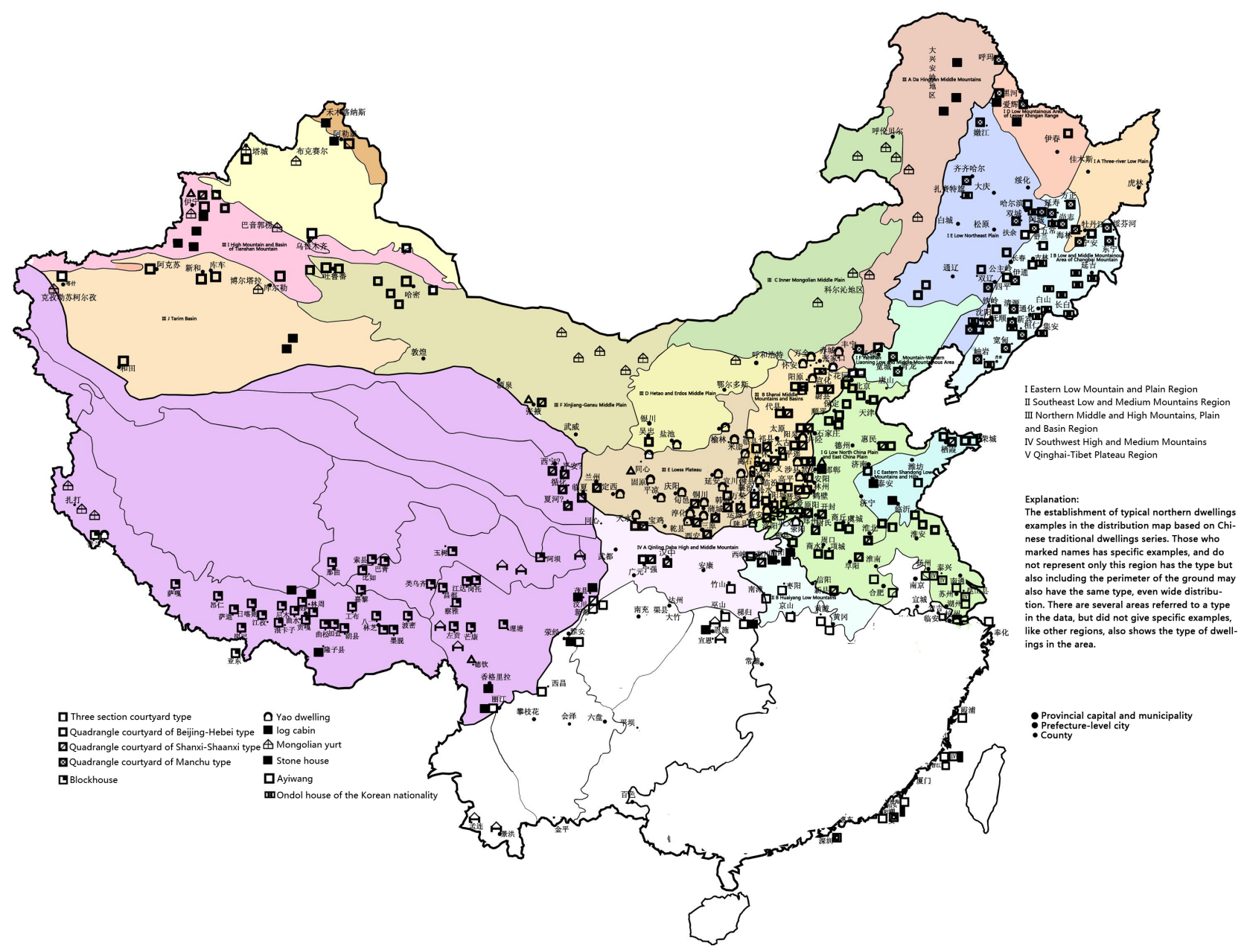

Fig. 10. Distribution map of typical dwellings in different geomorphological regions in northern China (Source: Drawn by the author)

as quadrangle courtyards of the Beijing-Hebei type and the Manchu type, with the dominant type shifting from the Manchu type to the Beijing-Hebei type from the north to the south. Additionally, ondol houses of the Korean nationality, log cabins, and stone houses can also be found in the region.

It can be seen from the distribution map that Region I is dominated by the plain topography, which provides a favourable environment for building courtyards, which is why a large number of quadrangle courtyards are present here. The gradual change of courtyard space results from multiple factors including climatic and cultural ones. There are also log cabins and stone houses in some areas. Log cabins are distributed in areas including the Low Mountainous Area of Lesser Khingan Range ID, because deep in the forest regions of the Lesser Khingan Range and the Changbai
Mountain are abundant timber resources, providing ample materials for building log cabins. Stone houses are distributed in Low North China Plain and East China Plain IG, mainly in the Taihang Mountains, such as Handan of Hebei Province and Anyang, Jiaozuo, and Xinxiang in Shanxi Province and northern Henan Province.

Northern Middle and High Mountains, Plain and Basin Region III is located in the northern part of the second topography ladder, with the Kunlun Mountains-Altun Mountains-Qilian MountainsQinling Mountains on the south, the Greater Khingan Range-Taihang Mountains on the east, and the frontier on the northwest. This region is featured by inland basins and plateaus at an elevation of about $1,000 \mathrm{~m}$, such as the Tarim Basin, the Junggar Basin, the Hexi Corridor, the Inner Mongolian middle plain, and the Loess Plateau, which are separated 
TABLE I. DISTRIBUTION OF TYPICAL TYPES OF DWELLINGS IN DIFFERENT GEOMORPHOLOGICAL REGIONS IN NORTHERN CHINA

\begin{tabular}{|c|c|c|c|}
\hline \multicolumn{2}{|c|}{ Geomorphological Region } & \multicolumn{2}{|c|}{ Distribution of Dwelling Types } \\
\hline & Landform No. & Major Types & Minor Types \\
\hline \multirow{7}{*}{$\begin{array}{l}\text { Eastern Low } \\
\text { Mountain and } \\
\text { Plain Region I }\end{array}$} & Three-river Low Plain IA & & Quadrangle courtyards of the Manchu type \\
\hline & $\begin{array}{l}\text { Low and Middle Mountainous } \\
\text { Area of Changbai Mountain IB }\end{array}$ & $\begin{array}{l}\text { Ondol houses of the Korean } \\
\text { nationality, quadrangle } \\
\text { courtyards of the Manchu type }\end{array}$ & $\begin{array}{l}\text { Quadrangle courtyards of the Beijing- } \\
\text { Hebei type }\end{array}$ \\
\hline & $\begin{array}{l}\text { Eastern Shandong Low } \\
\text { Mountains and Hills IC }\end{array}$ & $\begin{array}{l}\text { Quadrangle courtyards of the } \\
\text { Beijing-Hebei type }\end{array}$ & $\begin{array}{l}\text { Quadrangle courtyards of the Shanxi- } \\
\text { Shaanxi type, stone houses }\end{array}$ \\
\hline & $\begin{array}{l}\text { Low Mountainous Area } \\
\text { of Lesser Khingan Range ID }\end{array}$ & Log cabins & Quadrangle courtyards of the Manchu type \\
\hline & Low Northeast Plain IE & & $\begin{array}{l}\text { Ondol houses of the Korean nationality, } \\
\text { quadrangle courtyards of the Manchu type }\end{array}$ \\
\hline & $\begin{array}{l}\text { Yanshan Mountain-Western } \\
\text { Liaoning Low and Middle } \\
\text { Mountainous Area IF }\end{array}$ & $\begin{array}{l}\text { Quadrangle courtyards of } \\
\text { the Beijing-Hebei type }\end{array}$ & Quadrangle courtyards of the Manchu type \\
\hline & $\begin{array}{l}\text { Low North China Plain and } \\
\text { East China Plain IG }\end{array}$ & $\begin{array}{l}\text { Quadrangle courtyards of } \\
\text { the Beijing-Hebei type }\end{array}$ & $\begin{array}{l}\text { Quadrangle courtyards of the Shanxi- } \\
\text { Shaanxi type, stone houses, rammed earth } \\
\text { houses, cave dwellings }\end{array}$ \\
\hline $\begin{array}{l}\text { Southeastern } \\
\text { Low and Middle } \\
\text { Mountainous } \\
\text { Region II (junction } \\
\text { of the south and the } \\
\text { north) }\end{array}$ & $\begin{array}{l}\text { Huaiyang Low Mountains } \\
\text { IIB }\end{array}$ & & $\begin{array}{l}\text { Quadrangle courtyards of the Shanxi- } \\
\text { Shaanxi type, quadrangle courtyards of the } \\
\text { Beijing-Hebei type, stone houses }\end{array}$ \\
\hline \multirow{8}{*}{$\begin{array}{l}\text { Northern Middle } \\
\text { and High } \\
\text { Mountains, Plain } \\
\text { and Basin Region } \\
\text { III }\end{array}$} & $\begin{array}{l}\text { Shanxi Middle Mountains } \\
\text { and Basins IIIB }\end{array}$ & $\begin{array}{l}\text { Quadrangle courtyards } \\
\text { of rge Shanxi-Shaanxi type, } \\
\text { quadrangle courtyards of } \\
\text { the Beijing-Hebei type }\end{array}$ & cave dwellings \\
\hline & $\begin{array}{l}\text { Inner Mongolian Middle } \\
\text { Plain IIIC }\end{array}$ & Mongolian yurts & \\
\hline & $\begin{array}{l}\text { Hetao and Erdos Middle } \\
\text { Plain IIID }\end{array}$ & & $\begin{array}{l}\text { Quadrangle courtyards of the Beijing- } \\
\text { Hebei type, cave dwellings, Mongolian } \\
\text { yurts }\end{array}$ \\
\hline & Loess Plateau IIIE & $\begin{array}{l}\text { Cave dwellings, } \\
\text { quadrangle courtyards } \\
\text { of the Shanxi-Shaanxi type }\end{array}$ & $\begin{array}{l}\text { Quadrangle courtyards of the Beijing- } \\
\text { Hebei type }\end{array}$ \\
\hline & $\begin{array}{l}\text { Xinjiang-Gansu Middle } \\
\text { Plain IIIF }\end{array}$ & Mongolian yurts & $\begin{array}{l}\text { Quadrangle courtyards of the Shanxi- } \\
\text { Shaanxi type, quadrangle courtyards of the } \\
\text { Beijing-Hebei type, Ayiwang }\end{array}$ \\
\hline & $\begin{array}{l}\text { Xinjiang-Gansu Middle } \\
\text { Plain IIIH }\end{array}$ & & Ayiwang, Mongolian yurts, log cabins \\
\hline & $\begin{array}{l}\text { High Mountain and Basin } \\
\text { of Tianshan Mountain IIII }\end{array}$ & & $\begin{array}{l}\text { Ayiwang, stone houses, quadrangle } \\
\text { courtyards of the Beijing-Hebei type, } \\
\text { quadrangle courtyards of the Shanxi- } \\
\text { Shaanxi type }\end{array}$ \\
\hline & Tarim Basin IIIJ & Ayiwang & Mongolian yurts, log cabins \\
\hline $\begin{array}{l}\text { Qinghai-Tibet } \\
\text { Plateau V }\end{array}$ & & Blockhouses & $\begin{array}{l}\text { Stone houses, pile supported buildings, } \\
\text { Mongolian yurts }\end{array}$ \\
\hline
\end{tabular}

(Source: Drawn by the author) 
by high mountains. Dwellings in this region are dispersively distributed and are diversified. Among the sub-regions, the Shanxi Middle Mountains and Basins III B and Loess Plateau III E are some representative examples.

From the distribution map above, it can be seen that courtyard houses are more concentrated in the Shanxi Middle Mountains and Basins and the Loess Plateau, where plains and basins with a flat terrain are the dominant landforms, suitable for building courtyard houses. There are four minor landforms in the Shanxi Middle Mountains and Basins III B, i.e., the small- and medium-relief middle mountains and basins in Northern Shanxi, the medium- and large-relief middle and high mountains in the Taihang Mountains, the Midsouthern Shanxi basin, and the medium- and largerelief middle and high mountains in the Lvliang Mountain, mainly covering Shanxi Province, Hebei Province, Henan Province, and some areas in Inner Mongolia from the perspective of administrative division. There are a relatively large number of quadrangle courtyards of the Beijing-Hebei type and the Shanxi-Shaanxi type in this region. Since this region is in the zone of transition from North China to Northwest China, there are quadrangle courtyards of the Beijing-Hebei type distributed in Northern Shanxi adjacent to the Beijing-Hebei region; there are also quadrangle courtyards of the Shanxi-Shaanxi type distributed in the south of the Mid-southern Shanxi basin close to the Loess Plateau. Moreover, cave dwellings can also be seen in this region, distributed in the Mid-southern Shanxi basin and the medium- and large-relief middle and high mountains in the Taihang Mountains, as well as in western Henan Province.

The Loess Plateau III E has the largest area of loess in the world, covering a vast area on the west of the Taihang Mountains, east of the Riyue Mountain of Qinghai Province, north of the Central Shaanxi Plain, and south of the Great Wall and spanning over Shanxi Province, northern Shaanxi Province, Gansu Province, Qinghai Province, Ningxia Hui Autonomous Region, and Henan Province. A great number of cave dwellings and quadrangle courtyards of the Shanxi-Shaanxi type are distributed here. The quadrangle courtyards of the Shanxi-Shaanxi type are mostly found in central Shaanxi and southwestern Shanxi, and cave dwellings in southeastern Gansu, Guyuan of Ningxia, northern Shaanxi, mid-southern Shanxi, and southwestern Henan, because loessial gullies and loessland under this landform provide favourable conditions for building cave dwellings. Besides, cave dwellings are suitable for such dry and rainless loessial areas in the northwest with the advantages of easy and cheap to build, warm in winter and cool in summer, little ecological impact, and no occupation of farmland.

In addition, Ayiwang dwellings in the Tarim Basin III J and Mongolian yurts in Inner Mongolian Middle Plain III $\mathrm{C}$ are unique dwelling types shaped by different geomorphological conditions. They are also vital to the respective ethnic group.

In conclusion, the distribution of typical dwellings in northern China is directly related to landforms. The geomorphological regions in the northern China include the eastern plain area and the northern plateaus, plains, and basins, each of which is dominated by dwelling types most suitable for the local landforms. Dwellings are mostly situated in plains and basins with a relatively flat terrain, and their distinctive architectural styles are shaped by different geomorphological factors, e.g., log cabins flourish where abundant timber resources are available and cave dwellings flourish where the suitable geological structure is present. The discussions on the dwelling distribution in different geomorphological regions will pave the way for more intensive studies on this subject.

\section{CONCLUSIONS}

This paper studies typical dwellings and settlements in northern China, analyses and discusses dwelling types and geomorphological influencing factors, and reaches the following conclusions:

Instead of basing the study on administrative districts as previous studies did, this study made a creative attempt to turn to the climate and geomorphological regions in the northern region for natural influencing factors, to clarify the relationship between settlements and natural factors such as the landform.

Building on previous studies, this paper systematically classifies the main dwelling types in the northern region into three-section courtyards, quadrangle courtyards, cave dwellings, mud houses, Mongolian yurts, Ayiwang, blockhouses, and ondol houses of the Korean nationality. Besides, quadrangle courtyards are further divided into the Beijing-Hebei type, the Shanxi-Shaanxi type, and the Manchu type. Such classification enables a comprehensively case study, and a distribution map of typical dwellings in northern China is drawn. 
This study suggests that dwellings are closely related to natural factors such as the landform and the climate, and they greatly embody the philosophy of green architecture. Therefore, this study paves the way for deeper exploration into the relationship between settlements/dwellings and natural elements, which remains an urgent task.

\section{ACKNOWLEDGMENTS}

The authors acknowledge the funding support from Shaanxi Social Science Foundation Project (2018H06), Study on green design idea system of traditional architecture in Weihe River basin under the system of "technology-culture"; Fundamental Research Expenses of Central Universities (Humanities and Social Sciences (300102419670)), Study on regional theory of rural settlement construction in Weihe River basin.

\section{REFERENCES}

Albrecht F., and Shaffer G. (2016). Regional Sea-Level Change along the Chilean Coast in the 21st Century. Journal of Coastal Research. 32 (6), 1322-1332.

Amin H., Arain B.A., Abbasi M.S., Jahangir T.M. and Amin F. (2018). Comparative study of Zn-phytoextraction potential in guar (Cyamopsis tetragonoloba L.) and sesame (Sesamum indicum L.): tolerance and accumulation. Geology, Ecology, and Landscapes. 2(1), 29-38.

Basak B.B., and Gajbhiye N.A. (2018). Herbage yield and bioactive principle of senna as influenced by micronutrient application in soil. Journal of Environmental Biology. 39 (1), 43-49.

Basheer A.O., Hanafiah M.M. and Abdulhasan M.J. (2017). A Study on Water Quality from Langat River, Selangor. Acta Scientifica Malaysia. 1(2), 01-04.

Chen Z.D. (2009). Xinjiang Dwellings. China Building Industry Press. Chinese Academy of Sciences. $<$ China Natural Geography $>$ Editorial Board, (1985): $<$ China Natural Geography Overview $>$. Science Press.

Daya B. and Pant K. (2017). Biomonitoring of Wetland Using Macrophytes and Macroinvertebrates. Malaysian Journal of Sustainable Agriculture. 1(1), 11-14.

Franco H., Gavín-Quinchuela T., Alvarado-Macancela N. and Carrión-Mero P. (2017). Participative analysis of socio-ecological dynamics and interactions. A case study of the manglaralto coastal aquifer, santa elenaecuador. Malaysian Journal of Sustainable Agriculture. $1(1), 19-22$.
Ghafar F., Nazrin N.N., Salleh M.R.M., Hadi N.N., Ahmad N., Hamzah A.A., Yusof Z.A.M. and Azman I.N. (2017). Total phenolic content and total flavonoid content in moringa oleifera seed. Science Heritage Journal. 1(1), 23-25.

Hou J.Y., and Wang J. (1999). Chinese Yao Dwellings. Henan Science and Technology Press.

Ismail H. and Hanafiah M.M. (2017). Management of End-Of-Life Electrical and Electronic Products: The Challenges and The Potential Solutions for Management Enhancement in Developing Countries Context. Acta Scientifica Malaysia. 1(2), 05-08.

Junior high school geography textbook (8 Grade) (2013): People's Education Press.

Li Z., Han C., and Gu T. (2018). Economics of biomass gasification: A review of the current status. Energy Sources Part B Economics Planning and Policy. 13 (2), 137-140.

Liu, Z.P. (2000). A Brief History of Chinese residential building city, houses, gardens. China Building Industry Press.

Neves D., Baptista P., Simoes M., Silva C.A., and Figueira J.R. (2018). Designing a municipal sustainable energy strategy using multi-criteria decision analysis. Journal of Cleaner Production. 176, 251-260.

Ren, M.E., and Yang, R.Z. (1961). Issues of physical geographical regionalization of China. Acta Geographica Sinica, 25, 1-3.

Shamsudin N.H., Wong C.F., Rahman N.Z.A. and Ali M.S.M. (2017). Tight repression of elastase strain $\mathrm{K}$ overexpression by Pt7 (A1/O4/O3) shuttle expression system. Science Heritage Journal. 1(1), 20-22.

Sharma D. and Yadav K.D. (2017). Vermicomposting of Flower Waste: Optimization of Maturity Parameter by Response Surface Methodology. Malaysian Journal of Sustainable Agriculture. 1(1), 15-18.

Shen Y., Zhao N., Xia M., Du X. (2017). A deep q-learning network for ship stowage planning problem. Polish Maritime Research. 24 (SI), 102-109.

Tariq W., Hussain S.Q., Nasir A., Tayyab N., Gillani S.H. and Rafiq A. (2017). Experimental Study on Strength and Durability of Cement and Concrete By Partial Replacement Of Fine Aggegate With Fly Ash. Earth Sciences Pakistan. 1(2), 07-11.

Wang S.H., and Li R. (2017). Forecasting dissolved oxygen and biochemical oxygen demand in a river with numerical solution of one-dimensional bod-do model. Applied Ecology and Environmental Research. 15 (3), 323-333.

Wang, J. (2009). North-west Dwellings. China Building Industry Press.

Wang, J.P., Xu, Q., and Han, W.C. (2009). Shaanxi Dwellings. China Building Industry Press. 
Yang, G.Q. (2014). Integrated characteristics of space and social significance of traditional Chinese settlements. Tongji University Journal Social Science Section, 25 (3), 60-61.

Yasin H., Usman M., Rashid H., Nasir A. and Randhawa I.A. (2017). Alternative Approaches for Solid Waste Management: A Case Study in Faisalabad Pakistan. Earth Sciences Pakistan. 1(2), 04-06.
Ye, Z.R. (2009). Beijing Dwellings. China Building Industry Press.

Zhou, L.J., and Chen, B.C. (2009): North-east Dwellings. China Building Industry Press.

Zuo, M.C., and Bai, X.C. (2012). Henan Dwellings. China Building Industry Press. 